\title{
Pembuatan Plastik Biodegradable dari Pati Biji Nangka
}

\author{
Biodegradable Plastic Made From Jackfruit Seed Starch \\ Nuryati $^{1 *}$, Jaka Darma Jaya ${ }^{1}$, Norhekmah ${ }^{1}$ \\ ${ }^{1}$ Jurusan Teknologi Industri Pertanian, Politeknik Negeri Tanah Laut, Jl. A.Yani, Km.6, \\ Desa. Panggung, kec. Pelaihari, kab Tanah Laut, Kalimantan Selatan 70815.Indonesia. \\ Email: nuryati@gmail.com
}

Naskah diterima: 09 April 2019; Naskah disetujui : 22 April 2019

\begin{abstract}
Jackfruit seeds are still not widely used, even still considered as a waste. Though the content is quite diverse, such as carbohydrates $36.7 \mathrm{~g}, 4.2 \mathrm{~g}$ protein, energy $165 \mathrm{kcal}$ with a starch content of $40-50 \%$. To reduce environmental pollution from plastics, biodegradable plastics are currently being developed from bacterial cellulose, chitin, chitosan, or flour contained in plants. Therefore, it will be tested for the manufacture of biodegradable plastic derived from jackfruit seeds. The purpose of this study was to characterize biodegradable plastic from jackfruit seed starch and to find out the best addition of glycerol which will produce the least percentage of residue. The method used in the study: making biodegradable plastic from jackfruit seed starch with variations of glycerol $2 \mathrm{ml}, 3 \mathrm{ml}$ and $4 \mathrm{ml}$. The parameters observed were water resistance, heat resistance test and biodegradability test. The results showed that the addition of $2 \mathrm{ml}$ glycerol produced plastic sheets with a smooth surface, thinner, clearer and transparent, no bubbles compared to other variations of glycerol. Likewise with the water resistance and heat resistance test, the addition of $2 \mathrm{ml}$ glycerol each produces the highest water resistance level of $91.67 \%$ with absorbed water of $8.33 \%$, heat resistance up to $105^{\circ} \mathrm{C}$. While the biodegradability test for the addition of $4 \mathrm{ml}$ glycerol produced a smaller percentage of plastic residue which was equal to $78.57 \%$ compared to other treatments namely $96.43 \%$ for white plastic bags as a control, $88.23 \%$ for adding glycerol $2 \mathrm{ml}$ and $81,25 \%$ for the addition of $3 \mathrm{ml}$ glycerol.
\end{abstract}

Keywords: biodegradable plastic, glycerol, jackfruit seed starch

\begin{abstract}
ABSTRAK
Biji nangka masih belum banyak dimanfaatkan, bahkan masih dianggap sebagai sampah. Padahal kandungannya cukup beragam, seperti karbohidrat $36,7 \mathrm{~g}$, protein $4,2 \mathrm{~g}$, energi 165 kkal dengan kandungan pati $40-50 \%$. Untuk mengurangi pencemaran lingkungan yang berasal dari plastik, saat ini sedang dikembangkan plastik biodegradable yang berasal dari selulosa bakteri, kitin, kitosan, atau tepung yang terkandung dalam tumbuhan. Oleh karena itu, akan diuji pembuatan plastik biodegradable yang berasal dari biji nangka. Tujuan dari penelitian ini adalah untuk melakukan karakterisasi plastik biodegradable dari pati biji nangka dan mencari penambahan gliserol terbaik yang akan menghasilkan persentase residu yang paling sedikit. Metode yang digunakan dalam penelitian: pembuatan plastik biodegradable dari pati biji nangka dengan variasi gliserol $2 \mathrm{~mL}, 3 \mathrm{~mL}$ dan $4 \mathrm{~mL}$. Parameter yang diamati adalah ketahanan air, uji ketahanan panas dan uji biodegradabilitas. Hasil penelitian menunjukkan bahwa penambahan gliserol 2
\end{abstract}


$\mathrm{mL}$ menghasilkan lembaran plastik dengan permukaan halus, lebih tipis, bening dan transparan, tidak terdapat gelembung dibandingkan variasi gliserol yang lainnya. Demikian juga dengan uji ketahanan air dan ketahanan panas, penambahan gliserol $2 \mathrm{~mL}$ masing-masing menghasilkan tingkat ketahanan air paling tinggi yakni sebesar 91,67\% dengan air yang diserap sebesar $8,33 \%$, ketahanan terhadap panas sampai dengan suhu $105^{\circ} \mathrm{C}$. Sedangkan untuk uji biodegradabilitas penambahan gliserol $4 \mathrm{ml}$ menghasilkan persentase residu plastik yang lebih sedikit yakni sebesar 78,57\% di banding dengan perlakuan lain yakni $96,43 \%$ untuk kantong plastik putih sebagai kontrol, 88,23\% untuk penambahan gliserol $2 \mathrm{~mL}$ dan $81,25 \%$ untuk penambahan gliserol $3 \mathrm{~mL}$.

Kata kunci: plastik biodegradable, gliserol, pati biji nangka

\section{PENDAHULUAN}

Permasalahan sampah plastik merupakan suatu kendala yang tidak mudah ditanggulangi. Data statistik Kementerian Lingkungan Hidup (2008), sampah plastik yang dihasilkan sebesar 5,4 juta ton/tahun. Peningkatan penggunaan barang-barang yang berbahan dasar plastik berbanding lurus terhadap sampah plastik yang dihasilkan dan pada akhirnya akan berpengaruh terhadap rusaknya keseimbangan alam (Pimpan dkk, 2009).

Plastik yang digunakan saat ini adalah plastik non-biodegradable (plastik yang tidak dapat terurai secara biologis) yang terbuat dari minyak bumi yang keberadaannya semakin menipis dan tidak dapat diperbaharui, akibatnya semakin banyak penggunaan plastik semakin meningkat pula pencemaran lingkungan seperti penurunan kualitas air dan tanah menjadi tidak subur karena plastik tidak dapat dihancurkan dengan cepat dan alami oleh mikroba di dalam tanah.

Untuk mengurangi pencemaran lingkungan tersebut, saat ini sedang dikembangkan plastik biodegradable, yakni plastik yang dapat duraikan kembali oleh mikroorganisme secara alami menjadi senyawa yang ramah lingkungan. Plastik biodegradable terbuat dari polimer alami. Jenisnya antara lain polyhidroksialkanoat acid (PHA) dan poli-asam amino yang berasal dari sel bakteri; polylactic acid (PLA) yang merupakan modifikasi asam laktat hasil perubahan zat tepung/pati oleh mikroorganisme; dan poliaspartat sintesis yang dapat terdegradasi. Bahan dasar plastik berasal dari selulosa bakteri, kitin, kitosan, atau tepung yang terkandung dalam tumbuhan, serta beberapa material plastik atau polimer lain yang terdapat di sel tumbuhan dan hewan (Kartika, 2012). 
Sumber pati yang bisa dimanfaatkan untuk pembuatan plastik biodegradable adalah biji nangka. Biji nangka yang diperoleh dari buah nangka yang sudah matang. Dalam biji 100 g biji nangka mengandung karbohidrat 36,7 gram, protein 4,2 gram, energi $165 \mathrm{kkal}$, dan pati yang relatif tinggi sekitar 40-50\% (Pranamuda, 2011). Tingginya kandungan pati biji nangka tersebut, dapat dimanfaatkan menjadi suatu produk yang mempunyai nilai guna yaitu membuat plastik biodegradable berbahan dasar pati biji nangka penggunaan bahan-bahan yang alami diharapkan dapat mengurangi penumpukan sampah plastik dan dapat memanfaatkan limbah yang tidak dapat dipakai. Penelitian ini bertujuan untuk melakukan karakterisasi terhadap plastik biodegradable yang dibuat dari biji nangka dengan menambahkan beberapa variasi gliserol serta untuk mendapatkan plastik biodegradable dengan tingkat prosentase residu plastik paling sedikit.

\title{
METODE PENELITIAN
}

\begin{abstract}
Alat
Peralatan yang digunakan dalam penelitian ini yaitu baskom, pisau, blander, kain/sapu tangan, nampan, neraca analitik, mortar, gelas beaker, gelas ukur, gunting, penggaris, hot plate, batang pengaduk dan cetakan kaca.
\end{abstract}

\section{Bahan}

Bahan utama yang digunakan dalam penelitian ini yaitu pati biji nangka, sedangkan bahan pendukung adalah gliserol, asam asetat, aquades, air, tisue, pot dan tanah.

\section{Pembuatan Pati Biji Nangka}

Pembuatan pati biji nangka dengan cara yaitu biji nangka dikupas dari kulitnya kemudian ditambahkan air dan diblender sampai jadi bubur, lalu diperas menggunakan kain/sapu tangan. Hasil perasan didiamkan selama 24 jam untuk mendapatkan pati. Setelah 24 jam mendapatkan endapan pati kemudian dikeringkan di bawah sinar matahari hingga kering.

\section{Pembuatan Plastik Biodegradable Dari Pati Biji Nangka}

Pati biji nangka diambil sebanyak 12 gram dimasukkan kedalam gelas beaker, kemudian ditambahkan $25 \mathrm{~mL}$ aquades. Setelah diperoleh campuran pati biji nangka dengan aquades, tambahkan $3 \mathrm{ml}$ asam asetat yang berfungsi sebagai pelarut kemudian 
ditambahkan kembali dengan variasi (gliserol $2 \mathrm{ml}, 3 \mathrm{ml}$ dan $4 \mathrm{ml}$ ) gliserol yang berfungsi sebagai plastisizer lalu campuran tersebut dipanaskan dengan suhu $70-80^{\circ} \mathrm{C}$ sambil diaduk. Setelah mengental dicetak diatas cetakan yang berbahan dasar kaca. Kemudian dikeringkan di bawah sinar matahari selama 5 menit kemudian didiamkan pada suhu ruangan selama 24 jam (Anita dkk, 2013).

\section{Uji Karakterisasi}

\section{Uji ketahanan air}

Kantong plastik putih dan plastik biodegradable dipotong dengan ukuran $1 \mathrm{~cm}$ $\times 1 \mathrm{~cm}$. Plastik yang telah dipotong kemudian ditimbang dengan neraca analitik. Setelah itu, plastik dimasukkan ke dalam gelas beker $10 \mathrm{ml}$ yang telah diisi aquades sebanyak 5 $\mathrm{mL}$, kemudian didiamkan selama 1 menit lalu diangkat dan dikeringkan menggunakan tissue dengan hati-hati (Darni dkk, 2009). Plastik kemudian ditimbang dan dihitung air yang diserap serta ketahanan air pada plastik dengan menggunakan rumus:

Air yang diserap $=\frac{(\mathrm{W}-\mathrm{w} 0)}{W} \times 100 \%$

Keterangan: $\quad \mathrm{W}=$ Berat akhir sampel

$\mathrm{W}_{0}=$ Berat awal sampel

Ketahanan air plastik $=100 \%$ - persen air yang diserap

\section{Uji ketahanan panas}

Uji ini diperlukan untuk mengetahui temperatur dari sampel plastik biodegradable dan kantong plastik putih. Kedua sampel dipotong dengan ukuran $2 \mathrm{~cm} \times$ $2 \mathrm{~cm}$, kemudian dilakukan penumbukan menggunakan mortar hingga halus. Sampel plastik yang telah halus dimasukkan pada beaker glass dan diletakkan di atas hot plate. Setelah itu, suhu dicatat pada rentang suhu sampel sampai mengkerut (Fibriyani dkk, 2017).

\section{Uji biodegradabilitas}

Berdasarkan penelitian Nathiqoh (2013), tentang uji biodegradabilitas dengan metode soil burial test atau metode dengan penguburan dalam tanah dengan tujuan untuk melihat laju degradasi sampel sehingga berapa lama sampel tersebut akan terurai oleh mikroorganisme dalam tanah. Sampel penelitian berupa kantong plastik putih dan plastik biodegradable yang dipotong dengan ukuran $5 \mathrm{~cm} \times 1 \mathrm{~cm}$, sampel ditimbang lalu 
ditanamkan pada tanah yang ditempatkan dalam pot dan diamati 3 hari sekali, kemudian sampel ditimbang sampai diperoleh berat konstan. Setelah itu, dihitung \% residual plastik biodegradable dengan menggunakan rumus:

$\%$ residual plastik biodegradable $=100 \%-\frac{w_{1}-w_{2}}{w_{1}} \times 100 \%$

Keterangan: $\quad \mathrm{W}_{1}=$ Berat awal sampel

$\mathrm{W}_{2}=$ Berat akhir sampel

\section{HASIL DAN PEMBAHASAN}

\section{Pembuatan Plastik Biodegradable dari Pati Biji Nangka}

Hasil pembuatan plastik biodegradable dari biji nangka yang ditambahkan dengan gliserol disajikan pada Tabel 1 berikut.

Tabel 1. Hasil pembuatan plastik biodegradable dari pati biji nangka

\begin{tabular}{|c|c|c|c|}
\hline $\begin{array}{c}\text { Jenis } \\
\text { perlakuan }\end{array}$ & Warna & Bentuk & Plastik biodegradable \\
\hline $\mathrm{A}$ & $\begin{array}{l}\text { Bening dan } \\
\text { transparan }\end{array}$ & $\begin{array}{l}\text { Semua permukaan } \\
\text { halus dan tipis }\end{array}$ & \\
\hline B & $\begin{array}{l}\text { Bening } \\
\text { kecoklatan }\end{array}$ & $\begin{array}{l}\text { Permukaan yang } \\
\text { kasar, terdapat sedikit } \\
\text { gelembung dan } \\
\text { sedikit tebal }\end{array}$ & \\
\hline $\mathrm{C}$ & $\begin{array}{l}\text { Bening } \\
\text { kecoklatan }\end{array}$ & $\begin{array}{l}\text { Permukaan yang } \\
\text { kasar, mudah rusak, } \\
\text { terdapat sedikit } \\
\text { gelembung dan lebih } \\
\text { tebal }\end{array}$ & \\
\hline angan: & $\begin{array}{l}\mathrm{A}=\text { penambahan } \\
\mathrm{B}=\text { penambahan } \\
\mathrm{C}=\text { penambahan }\end{array}$ & $\begin{array}{l}\text { liserol } 2 \mathrm{~mL} \text {, } \\
\text { liserol } 3 \mathrm{~mL} \text {, dan } \\
\text { liserol } 4 \mathrm{~mL}\end{array}$ & \\
\hline
\end{tabular}

Proses pembuatan plastik biodegradable dari pati biji nangka dilakukan dengan tiga tahapan. Tahap pertama dalam pembuatan dengan melakukan pencampuran pati biji nangka dengan aquades. Aquades ini digunakan sebagai pelarut. Kemudian sampel 
tersebut dicampurkan dengan gliserol. Gliserol ini berfungsi sebagai pemlastis yang akan memberikan fleksibilitas pada struktur pati sehingga dapat bisa dibentuk. Tahap berikutnya dilakukan pencampuran pada asam asetat. Tahap kedua yaitu pembentukan polimer yang dipanaskan menggunakan hot plate dengan suhu $70-80^{\circ} \mathrm{C}$, karena pada suhu tersebut larutan akan melunak sehingga memudahkan dalam proses pencetakan plastik. Tahap ketiga yaitu proses pencetakan plastik yang dicetak dengan cetakan berbahan dasar kaca.

Hasil dari pembuatan plastik biodegradable dari pati biji nangka dilihat pada Tabel 1. Plastik lebih bagus pada penambahan gliserol $2 \mathrm{~mL}$ (A) dapat terlihat pada lembaran plastik semua permukaan halus, lebih tipis, bening dan transparan, tidak terdapat gelembung. Dalam penambahan gliserol berfungsi sebagai pemlastis agar bisa lebih elastis pada plastik. Dibandingakan penambahan gliserol $3 \mathrm{~mL}(\mathrm{~B})$ dan penambahan gliserol $4 \mathrm{~mL}$ (C) dapat terlihat permukaan kasar, sedikit gelembung, mudah rusak dan bewarna kecoklatan hal ini disebabkan karena semakin banyak penambahan gliserol akan mengakibatkan plastik mudah rapuh karena sifat elastis pada plastik terlalu besar. Semakin meningkatnya konsentrasi gliserol, maka gelembung yang terdapat pada permukaan plastik akan semakin sedikit dan rongga gelembung akan semakin membesar. Hal ini dikarenakan gliserol mempunyai sifat hidrofilik yaitu dapat menyerap air, sehingga kelarutan gliserol juga semakin sedikit dan meningkat. Hasil penelitian ini sesuai dengan penelitian yang telah dilakukan oleh Fibriyani, dkk (2017), tentang pembuatan plastik biodegradable dari tepung onggok singkong dengan penambahan gliserin dari minyak jelantah telah didapatkan plastik biodegradable berupa lembaran berwarna sedikit coklat muda, transparan dan elastis. Plastik biodegradable berbahan dasar pati memiliki kelemahan antara lain tidak tahan terhadap panas, sifat mekanis yang rendah, tidak tahan terhadap mikroorganisme dan air. Semakin banyak gliserin yang digunakan maka sifat plastik akan semakin elastis.

\section{Uji Ketahanan Air dan Uji Ketahanan Panas}

Hasil perbandingan uji ketahanan air dan uji ketahanan panas pada kantong plastik putih serta plastik biodegradable dengan penambahan gliserol $2 \mathrm{~mL}$ (A), $3 \mathrm{~mL}$ (B), dan $4 \mathrm{~mL}$ (C) dapat dilihat pada Tabel 2. 
Tabel 2. Nilai ketahanan air dan ketahanan panas pada kantong plastik putih dengan plastik biodegradable dari pati biji nangka

\begin{tabular}{cccc}
\hline $\begin{array}{c}\text { Jenis } \\
\text { perlakuan }\end{array}$ & $\begin{array}{c}\text { \% Air yang } \\
\text { diserap }\end{array}$ & $\begin{array}{c}\text { \% Ketahanan } \\
\text { air }\end{array}$ & $\begin{array}{c}\text { Suhu ketahanan } \\
\text { panas }\end{array}$ \\
\hline $\begin{array}{c}\text { Kantong plastik } \\
\text { putih }\end{array}$ & 4,54 & 95,46 & $130^{\circ} \mathrm{C}$ \\
$2 \mathrm{~mL}(\mathrm{~A})$ & 8,33 & 91,67 & $105^{\circ} \mathrm{C}$ \\
$3 \mathrm{~mL}(\mathrm{~B})$ & 11,11 & 88,89 & $90^{\circ} \mathrm{C}$ \\
$4 \mathrm{~mL}(\mathrm{C})$ & 14,28 & 85,72 & $85^{\circ} \mathrm{C}$ \\
\hline Keterangan: & $\mathrm{A}=$ penambahan gliserol $2 \mathrm{~mL}$, & \\
& $\mathrm{B}=$ penambahan gliserol $3 \mathrm{~mL}$, dan & \\
& $\mathrm{C}=$ penambahan gliserol $4 \mathrm{~mL}$
\end{tabular}

Berdasarkan hasil data pada Tabel 2, perbandingan uji ketahanan air pada kantong plastik putih tingkat ketahanan air sebesar 95,46\% dengan air diserap 4,54\% sedangkan pembuatan plastik biodegradable dari pati biji nangka dengan penambahan gliserol $2 \mathrm{~mL}$ (A) tingkat ketahanan air 91,67\% dengan air diserap sebesar 8,33\%. Semakin rendah air diserap pada suatu plastik maka ketahanan airnya semakin tinggi (Anita, 2013), sedangkan air diserap rendah akan menjadi pembengkakan (swelling). Penyerapan air yang tertingggi sebesar 14,28\% dengan penambahan gliserol $4 \mathrm{~mL}$ (C) yang akan mengakibatkan plastik lebih mudah rusak dan terurai, karena adanya air diserap pada plastik sehingga memudahkan mikroorganisme (jamur dan bakteri) untuk mempercepat proses degradasi. Hal ini disebabkan karena gliserol sebagai sifat elastis maka menambah kelenturan plastik.

Menurut Nurhayati (2013), hasil penelitian sintesis plastik biodegradable amilum biji durian dengan gliserol sebagai penambahan elastisitas (plasticizer) dengan penambahan kitosan dan gliserol mempunyai ketahanan air yang baik jika dibandingkan dengan plastik biodegradable tanpa penambahan kitosan. Hal ini disebabkan oleh sifat kitosan yang hidrofil sehingga plastik biodegradable akan cenderung lebih tahan terhadap air meskipun plastik yang dihasilkan masih bersifat hidrofil. Ketahanan air yang paling baik terdapat pada komposisi plastik perbandingan pati:kitosan 4:6. Nilai persen air yang diserap akan berbanding terbalik dengan ketahanan air dari plastik, semakin kecil nilai persen air yang diserap oleh plastik, maka semakin besar ketahanan air yang dimiliki oleh plastik tersebut. Penelitian Nurhayati, dkk (2013) menunjang penelitian penulis, bahwa penggunaan pati dengan penambahan pengelastis seperti kitosan dan gliserol dalam pembuatan kantong plastik biodegradable adalah lebih baik karena akan menghasilkan kantong plastik yang lebih mudah terurai di bandingkan plastik non-biodegradable. 
Pengujian ketahanan panas mengalami kendala dalam penggunaan alat uji yaitu melting block sehingga dalam melakukan pengujian ketahanan panas digunakan alat pemanas yaitu dengan menggunakan hot plate. Berdasarkan hasil yang diperoleh hasil pemanasan pada sampel yang dapat diamati hanya pengerutan pada sampel.

Berdasarkan data pada Tabel 2, perbandingan uji ketahanan panas pada kantong plastik putih mengalami pengerutan pada suhu $130^{\circ} \mathrm{C}$ dan pembuatan plastik biodegradable dari pati biji nangka penambahan gliserol $2 \mathrm{~mL}$ mengalami pengerutan pada suhu $105^{\circ} \mathrm{C}$, sedangkan penambahan gliserol $3 \mathrm{~mL}$ mengalami pengerutan pada suhu $90^{\circ} \mathrm{C}$ serta penambahan gliserol $4 \mathrm{~mL}$ mengalami pengerutan pada suhu $85^{\circ} \mathrm{C}$. Berdasarkan hasil tersebut dapat diketahui bahwa semakin banyak penambahan gliserol pada pembuatan plastik biodegradable, maka semakin rendah suhu yang dihasilkan. Sebaliknya, semakin sedikit gliserol yang ditambahkan, semakin tinggi suhu yang dihasilkan. Selain itu semakin tinggi suhu yang dihasilkan semakin besar ketahanan panas dan titik leleh yang dihasilkan.

Hasil penelitian ini juga didukung dari penelitian sebelumnya yang dilakukan oleh Rahardianto, dkk (2013) yaitu melakukan penelitian terhadap pembuatan plastik biodegradable dari pati ubi kayu. Hasil yang diperoleh pada penelitian tersebut ialah semakin sedikit gliserol yang ditambahkan pada pembuatan plastik biodegradable dari pati ubi kayu, maka semakin tinggi titik leleh yang dihasilkan, begitu pula sebaliknya.

\section{Uji Biodegradabilitas}

Pengujian biodegradabilitas ini dilakukan pada 4 buah sampel kantong plastik putih dan plastik biodegradable dengan variasi gliserol $2 \mathrm{~mL}$ (A), $3 \mathrm{~mL}$ (B), dan $4 \mathrm{~mL}$ (C) dapat dilihat pada Tabel 3.

Tabel 3. Hasil uji biodegradabilitas plastik

\begin{tabular}{|c|c|c|c|c|c|c|c|c|}
\hline \multirow{2}{*}{$\begin{array}{c}\text { Jenis } \\
\text { perlakuan }\end{array}$} & \multicolumn{4}{|c|}{ Berat plastik (gram) } & \multicolumn{4}{|c|}{ \% Residual plastik } \\
\hline & 0 hari & 3 hari & 6 hari & 9 hari & 0 hari & 3 hari & 6 hari & 9 hari \\
\hline $\begin{array}{l}\text { Kantong } \\
\text { plastik putih }\end{array}$ & 0,30 & 0,29 & 0,28 & 0,27 & 100 & 96,67 & 96,55 & 96,43 \\
\hline $2 \mathrm{~mL}(\mathrm{~A})$ & 0,20 & 0,19 & 0,17 & 0,15 & 100 & 95,00 & 89,47 & 88,23 \\
\hline $3 \mathrm{~mL}$ (B) & 0,20 & 0,18 & 0,16 & 0,13 & 100 & 90,00 & 88,89 & 81,25 \\
\hline $4 \mathrm{~mL}(\mathrm{C})$ & 0,20 & 0,17 & 0,14 & 0,11 & 100 & 85,00 & 82,35 & 78,57 \\
\hline Keterangan: & $\begin{array}{l}\mathrm{B}=\text { per } \\
\mathrm{C}=\text { per }\end{array}$ & han $g$ & $\begin{array}{l}2 \mathrm{~mL} \text {, } \\
3 \mathrm{~mL} \text {, } \\
4 \mathrm{~mL}\end{array}$ & & & & & \\
\hline
\end{tabular}

Berdasarkan uji biodegradabilitas hasil dari prosentase residual pada kantong plastik putih dan plastik biodegradable dilihat pada Tabel 3. Sisa berat plastik ditimbang 
pada tiap 3 hari sekali selama 9 hari penguburan dalam tanah. Sampel kantong plastik putih sebesar 96,43\% sedangkan plastik biodegradable dari pati biji nangka dengan penambahan gliserol $2 \mathrm{~mL}$ (A) kemampuan terdegradasinya ditunjukan banyaknya sisa berat plastik sebesar 88,23\%, untuk gliserol $3 \mathrm{~mL}$ (B) sisa berat plastik $81,25 \%$ dan penambahan gliserol $4 \mathrm{~mL}$ (C) menghasilkan sisa berat plastik yang berkurang sebesar $78,57 \%$ menunjukan hasil degradasi yang baik karena plastik tersebut lebih cepat terurai oleh mikroorganisme. Hal ini disebabkan karena semakin banyaknya jumlah penambahan gliserol yang digunakan maka akan semakin banyak pula bagian dari plastik yang akan terdegradasi karena gliserol memiliki sifat hidrofilik (menyerap air).

Jika dibandingkan kantong plastik putih dengan plastik biodegradable menurut ASTM D 6400, plastik telah terbukti terurai dalam waktu sangat lama sekitar 50 tahun agar dapat terdekomposisi di alam, karena bahan baku pembuatan adalah minyak bumi terutama hidrokarbon rantai pendek. Sedangkan plastik biodegradable menurut standar ASTM 5336 untuk tingkat degradasi 100\% dibutuhkan waktu 60 hari golongan Polillactid acid (PLA). PLA adalah plastik biodegradable yang berasal dari pati, tapioka, kentang maupun yang mengandung glukosa lainnya.

Hasil penelitian ini juga didukung dari penelitian sebelumnya yang dilakukan oleh Pratiwi, dkk (2016), berdasarkan penelitian tentang hasil pembuatan plastik biodegradable dari bonggol pisang kepok penggunaan gliserol $4 \mathrm{~mL}$ menunjukan kemampuan penyerapan air yang lebih besar dibandingkan dengan penggunaan gliserol 3 $\mathrm{mL}$. Semakin banyak kandungan air dalam material maka akan semakin mudah plastik untuk terdegrdasi. Selain gliserol, selulosa juga dapat meningkatkan kemampuan terdegradasi pada plastik karena mempunyai gugus hidroksil $\mathrm{OH}$ yang menginisiasi reaksi hidrolisis setelah mengabsorbsi air dalam tanah.

\section{KESIMPULAN}

Berdasarkan penelitian yang telah dilakukan dapat disimpulkan bahwa:

1. Karakterisistik plastik biodegradable yang dihasilkan adalah penambahan gliserol 2 $\mathrm{mL}$ menghasilkan lembaran plastik dengan permukaan halus, lebih tipis, bening dan transparan, tidak terdapat gelembung dibandingkan variasi gliserol yang lainnya. Demikian juga dengan uji ketahanan air dan ketahanan panas, penambahan gliserol 2 $\mathrm{mL}$ masing-masing menghasilkan tingkat ketahanan air paling tinggi yakni sebesar 
$91,67 \%$ dengan air yang diserap sebesar $8,33 \%$, ketahanan terhadap panas sampai dengan suhu $105^{\circ} \mathrm{C}$.

2. Uji biodegradabilitas penambahan gliserol $4 \mathrm{~mL}$ menghasilkan persentase residu plastik yang lebih sedikit yakni sebesar $78,57 \%$ di banding dengan perlakuan lain yakni $96,43 \%$ untuk kantong plastik putih sebagai kontrol, $88,23 \%$ untuk penambahan gliserol $2 \mathrm{~mL}$ dan $81,25 \%$ untuk penambahan gliserol $3 \mathrm{~mL}$.

\section{UCAPAN TERIMA KASIH}

Terimakasih diucapkan kepada Program Teknologi Industri Pertanian Politeknik Negeri Tanah Laut khususnya Laboratorium Pengujian Politeknik Negeri Tanah Laut yang memberikan fasilitas dalam melaksanakan penelitian ini, dan terimakasih kepada pihak yang telah membantu dalam pengerjaan Penelitian ini.

\section{DAFTAR PUSTAKA}

Akbar, F. A. Zulisma, H. Harahap,. (2013) Pengaruh Waktu Simpan Film Plastik Biodegradasi dari Pati Kulit Singkong terhadap Sifat Mekanikalnya. Jurnal Teknik Kimia USU. 2(2): 11-15.

Astuti Handayani dan Hesmita Wijayanti. (2015) Pempuatan Plastik Biodegradable dari Limbah Biji Durian. Universitas Negeri Semarang.

Darni, Y., Herti Utami, and Nur Asriah. (2009) Studi Hidrofobisitas dan Sifat Fisik Plastik Biodegradable Pati Tapioka dengan Penambahan Selolusa Residu Rumput laut Euchema Spinossum. Seminar Hasil Penelitian dan Pengabdian Kepada Masyarakat. Lampung Universitas Lampung.

Fibriyani. D, Arinta. F dan Kusumaningtyas. D. R. (2017) Pengolahan Onggok Singkong sebagai Plastik Biodegradable Menggunakan Plasticizer Gliserin dari Minyak Jelantah. Universitas Negeri Semarang, Semarang.

Kartika. M.I. (2012) Pembuatan Plastik Biodegradable dari Pati. https: www. kompasiana. com/ maharaniintan/.../pati-bahan-dasar-untuk membuat-plastik. 23 Mei 2012.

Nathiqoh. (2013) Uji Ketahanan Biodegradable Plastic Berbasis Tepung Biji Durian (Durio zibethinus murr) Terhadap Air dan Pengukuran Densitasnya. Universitas Negeri Semarang, Semarang.

Pimpan, Rinaldi and Suhadi. S. (2014) Pengaruh Penambahan Gliserol Terhadap Sifat Kekuatan Tarik dan Pemanjangan Saat Putus. 
Pranamuda. (2011) Pengembangan Bahan Plastik Biodegradabel Berbahan Baku Pati Tropis. http://wwwstd.ryu.titech.ac.jp/ indonesia/zoa/paper/htmL/papr.

Pratiwi. (2016) Pemanfaatan Bonggol Pisang Kepok (Musa paradisiaca. L) sebagai Bahan Pembuatan Plastik yang Mudah Terdegradasi dengan Penambahan Plasticizer Gliserol. Jurnal Atomatik. Vol 01(2). Hal: 104-106.

Rahardiyanto, Tri prasetyo and Rudiana Agustini (2013). Pengaruh Massa Gliserol Terhadap Titik Leleh Plastik Biodegradable dari Pati Ubi Kayu. Universitas Negeri Surabaya.

Utami. (2010) Studi Pembuatan dan Karakteristik Plastik Biodegradable dari Pati Sorgum. Jurnal Rekayasa Kimia dan Lingkungan. 7 (4). 190-195. 